\title{
Governance and Growth Challenges for Africa
}

\author{
Mushtaq H. Khan \\ SOAS, University of London
}

\begin{abstract}
The World Bank recognized the role of concerted state strategies in driving growth in a number of successful East Asian countries (World Bank 1993). However, this qualified recognition was attended with the observation that the appropriate state capacities for productive interventions were missing in most other developing countries. In these countries, attempts to replicate East Asian strategies would not only fail, but would make things worse due to static efficiency losses and rent-seeking costs. At one level, the World Bank's argument against growth-promoting strategies of the East Asian type in most developing countries is absolutely accurate. The appropriate governance capabilities are clearly absent in many of the poorest countries that are most in need of growth strategies. Moreover, an attempt to acquire state capabilities on a scale that would enable these countries to attempt the types of interventionist programmes seen in East Asian countries in the 1960s and 1970s is probably beyond the feasible capacity of reform in these developing countries.
\end{abstract}

However, while we recognize the obvious truth in the World Bank's analysis of the problem, their policy conclusion does not necessarily follow. The conclusion was that because the substantial growth-promoting governance capabilities of the East Asian economies did not exist in most other developing countries (and indeed could not be feasibly replicated) their optimal strategy was to abandon all growth-promoting strategies and resort to the alternative of seeking to promote market efficiency through market-enhancing governance. This does not follow because a market-enhancing governance strategy is equally over-ambitious in the demands it makes on state capabilities and focusing on this may not deliver any significant returns. To attempt to make markets in general work so efficiently that market failures are no longer a problem may be just as overambitious as the attempt to correct vast swathes of market failures through extensive interventions. In addition, there are structural reasons which set a ceiling to the development of market-enhancing governance capabilities in developing countries. Focusing purely on market-enhancing governance is therefore likely to yield disappointing results.

To take account of the limited reform capabilities in real contexts, a targeted approach to developing governance capabilities makes sense. The experience of successful developers suggests that growth-promoting governance was important, but many of the political and institutional initial conditions enjoyed by the successful countries of East Asia were indeed very different from those in Africa. Any simplistic attempt to learn the lessons of East Asia is therefore likely to be misleading because the scale of these growth-enhancing governance capabilities cannot be replicated in most contemporary developing countries. Attempts to do so are likely to result in significant government failures and the abandonment of these strategies. A more relevant approach for Africa is to learn from the experience of successful developers but aim for sequential and incremental "Hirschmanian" strategies of addressing critical constraints in particular areas where it is likely that the development of specific governance capabilities are feasible and can deliver results. 


\section{Good governance and the liberal economic analysis of Africa}

Developing countries in Africa, like elsewhere on the planet, do not fit the conditions that the good governance model identifies as necessary for economic development. As most African countries face difficult development problems, it has been easy to build coalitions arguing that governance capabilities as defined by the market-enhancing governance model were responsible for African misfortunes. In particular, the analysis that the lack of democratic accountability and the presence of patron-client politics, extensive corruption and a weak rule of law had a lot to do with Africa's relatively poor performance found many supporters within and outside Africa (Commission for Africa 2005). Indeed, to some extent these arguments are also true because it must be the case that less corruption is better than more, for instance. However, these arguments did not establish a) that these challenges were the most important ones for Africa, or b) that they could be addressed feasibly even if they were quite important. We discuss these two issues in turn in the context of the African debate and then turn to alternative approaches that African countries need to explore.

The argument that conventional market-enhancing governance was an important if not the most important constraint for Africa has been challenged by a number of empirical works. An influential argument coming from Jeffrey Sachs and his associates (Sachs, et al. 2004) argues that the specific characteristics of Africa in terms of low population density, vast areas, poor infrastructure and the prevalence of difficult diseases makes many of the conventional governance arguments irrelevant. What Africa requires, according to this argument is a "big push" in terms of massive investment in infrastructure and disease control before attention to governance can deliver any results. They use a sample of thirty-three sub-Saharan African countries to show two things. First, that once we adjust for their levels of income, only five of these countries have a governance level in 2002 as measured by the World Bank governance indicators that is below the level expected for their level of income. Eight have governance scores that are above the level we would expect for their level of income. The rest are average, meaning their scores are about what we would expect at their income levels. But even relatively well-governed African countries failed to significantly improve their living standards. Secondly, they show that even when governance indicators are included in a general regression exercise to explain growth of per capita incomes over 1980-2000, African countries as a group do particularly badly compared to other developing countries. The dummy variable for Africa suggests that African countries grew on average three per cent points less a year than we would expect for their per capita income and governance indicators.

We have already pointed out (Khan this volume) the general problems with establishing causality using regression analysis. In criticizing the results reported by Sachs and associates, Kaufmann et al. make the point that two-way causality undermines the argument made by Sachs (Kaufmann, et al. 2005). What they do not say is that the problem of two-way causality also undermines their own attempt to establish causality in the opposite direction, and that historical causality is difficult if not impossible to establish using regression analysis, particularly with data for a limited number of years. While the general argument for a big push in Africa can be supported, Sachs et al. underplay the importance of the governance capabilities that may also be required to implement the big push. Here, an evaluation of the historical experience of successful developers elsewhere is relevant for identifying the specific 
'growth-enhancing' governance capabilities that it will be important to develop in particular countries given the growth strategies they are attempting. Regression analysis is not likely to help much in identifying these strategies.

An influential approach arguing for the minimal state in Africa comes from Paul Collier (2007) drawing on much work done by his research team over the years. This is a sophisticated approach that makes distinctions in governance priorities for resource-rich and resource-poor African countries, further dividing the latter group into coastal and land-locked groups. However, the underlying presumption running through the analysis is that a minimalist state is least likely to do damage, and that a state that can create conditions for markets to work reasonably well will need to do little else. Free trade is the best option for African states (with some minor exceptions that we will discuss later). The role of the state is to use available tax resources to provide security and essential public goods and in the case of resource rich countries to smooth income fluctuations over time. The implicit assumption is that other market failures are not significant and that even in poor African countries market efficiency can be sufficiently improved through good governance type reforms for most market failures to disappear (see Khan this volume for a fuller discussion).

As these are claims about historical processes and not about the logical coherence of models, we argued that they need to be tested against a historical analysis of processes of transition in countries that have developed earlier. Collier does not engage in the bigger debate, but provides another set of regression exercises that purport to show that the underlying argument is valid. This is their analysis of state-created 'syndromes' that could explain why African countries did poorly in the 1980s when some other developing countries particularly in Asia experienced significant growth takeoffs. Drawing on Collier and O'Connell (2007), a number of 'syndromes' are identified which are essentially different aspects of state policies gone wrong. These include the mismanagement of natural resource windfalls (overspending in boom years and then having to cut back seriously in subsequent years), redistributive strategies (particularly those which benefit particular ethnic groups), excessive regulation (which is a malleable definition that can include a variety of policies that are not working) and state breakdown (conflict and civil war). The regression looks at the numbers of years between 1960-2000 when African countries suffered from 'syndromes' and the relationship with growth. The unsurprising finding is that the longer the period of syndromes, the poorer the growth performance. As the authors themselves point out, the absence of syndromes did not guarantee growth (no African country was a stellar performer), but syndromes were associated with growth declines. But clearly, these regressions cannot tell us what African states should do to achieve and sustain growth at the levels that successful developers elsewhere did, since the absence of syndromes does not help very much in Africa according to the authors themselves.

The problem is that these results are presented as showing that not messing with the market is the best policy option for African countries. In fact, what the results show is that intervening in wrong ways or without the capabilities to do so can be damaging. It does not show that not intervening achieves or sustains the growth rates that would allow any African country to converge towards advanced country standards of living. A historical approach would ask how successful developers achieved and sustained growth over decades. Would China's sustained intervention in exchange rates and 
interest rates over decades, or South Korea's intervention in its financial sector and in trade policy count as syndromes? The syndrome analysis is also used to argue that the reason why Africa did not benefit from globalization and the relocation of many manufacturing activities in the 1980 s is that many African countries were suffering from 'syndromes' just at that time (Collier 2007). However, in the 1990s when many African countries got rid of many of these 'syndromes', manufacturing still did not relocate to Africa. Collier pessimistically argues that this shows that Africa had simply 'missed the boat' and will have to wait for several decades till its wage gap with Asia is as great as Asia's was with the OECD in the 1980s. Unfortunately, if Africa waits for the market to solve all its problems it may have to wait even longer.

Fosu's application of the syndrome approach to African growth (this volume) is subject to the standard problems of attempting to resolve questions of historical transition using regression analysis for a limited set of countries over a limited period. It may well be true that if we look at a set of African countries over a limited period, fewer 'syndromes' were associated with higher growth. Even abstracting from problems of directions of causality and multiple explanations, there is an even more fundamental historical question of process that we discussed in an earlier chapter (Khan, this volume). Is there any example of a country that made the transition from poverty to high standards of living simply by getting rid of 'syndromes' as defined by these authors? I do not know of any.

We have to be even more careful about the governance conclusion in Fosu (this volume) that higher degrees of constraints on executives are associated with fewer 'syndromes'. Implicitly, the argument is that since being 'syndrome-free' is good, and since executive freedom is associated with a greater probability of 'syndromes', constraining developing country executives must be good. Deriving principles appropriate for historical processes from these types of correlations should obviously be treated with great care. Since there is no historical evidence that being 'syndromefree' is sufficient for transforming societies, constraining executives may be the wrong governance priority for developing countries, even if their current or past executives would appear to benefit from constraints. We need to understand why executives in some countries behave differently from others, because it is not the case in any historical comparison that successful developing countries had highly constrained executives.

Reading too much into correlations may have unintended consequences that the authors may not have considered. How might the United States have responded to the financial crisis of 2007-08 if its executive branch had been more constrained in its freedom of action? In comparison to advanced countries, developing countries are in a permanent state of crisis. They may commit a serious mistake by constraining their executives in the absence of strong historical evidence that unconstrained (syndromefree) markets and constrained executives have been sufficient for taking societies out of civil wars, deep structural crises and high levels of poverty into developed country status. Again, I do not know of any examples of such transitions. So while all regression exercises can provide useful insights, we should remember that answering big historical questions requires us to look at the historical evidence in addition to any econometric studies that may also be available. 
This discussion confirms what we said earlier, namely that different methods of analysis need to be recognized and they give very different answers to big historical questions. At least we can say that the regression analysis does not prove conclusively to anyone not already convinced that liberal markets and the governance capabilities for achieving these will be sufficient to ensure African prosperity. At most they allow us to say that if African states made egregious mistakes in the past, stopping these mistakes will make things a little better. But the first proposition does not follow from the second: stopping mistakes may not be sufficient for ensuring a developmental transformation of these societies.

We now come to the second question: to what extent is it even possible for African countries to make significant progress in achieving 'market-enhancing' good governance goals that are recommended for them? It is important to recognize the structural factors constraining progress towards good governance capabilities in the medium term. Some of these factors may also be a problem for developing growthenhancing governance capabilities, except that the latter recognizes that we can only develop limited areas of effective governance capabilities in most developing countries.

Stable property rights are expensive and take a long time to achieve. The achievement of property right stability in poor countries faces extensive structural constraints. North's analysis of property rights and transaction costs has implications that are often ignored: reducing transaction costs is itself very costly. In rich countries, almost all assets are productive and their owners pay very significant taxes and these pay for the protection of all property rights as a public good. In developing countries the tax base for protecting property rights as a public good simply does not exist in most cases, particularly in the poorest developing countries. Most assets are by definition in non-capitalist and low productivity sectors such as peasant agriculture and the informal sector. Typically these generate an insignificant surplus that is not sufficient to pay for the general protection of all assets through taxation. If stable property rights across the board cannot be achieved as a public good, institutional arrangements that protect critical investors are much more important, and these may often be informal institutions. Growth-promoting governance capabilities for managing investor property rights in developing countries can therefore often look very different from the good governance capabilities of establishing and protecting property rights as a public good (Qian 2003). What can look like a set of informal and ad hoc arrangements for protecting specific investments may well be the most effective institutional arrangement in a poor country to promote investments in critical areas.

Similarly, if property rights are not well-defined and transaction costs are high, investors may often be unable to purchase the assets they need, in particular land. The strategy of improving market efficiency in these cases may take too long and specific governance capabilities need to be developed to deal with the growth constraints emanating from high transaction cost asset markets. We saw in Khan (this volume) that non-settler colonies left many societies with conflicting and inappropriate property rights structures. For instance, only between 2 and 10 per cent of land in contemporary sub-Saharan Africa is held under freehold title while much of the rest is held in various forms of communal or customary tenures (Deininger 2003: 62). An important growth-enhancing governance capability that many of these countries need 
to develop is the institutional and political capability to develop industrial parks and other zones where high productivity agriculture and industry can be set up, with adequate compensation of prior rights holders, and perhaps involving them in new productive activities. It is not an accident that different types of land reform were an important prelude to growth in high growth economies. But in many countries it is important to be modest and not attempt too much. A specialized and high powered agency empowered to set up one or two industrial parks may stretch the reform capabilities of some countries, but it would be a huge achievement to show what can be done on a small scale (Khan 2009).

The fight against corruption is a long-term one. Corruption has multiple drivers and many of these are very difficult to attack in the short term in developing countries (Khan 2006b). A governance strategy that focuses on achieving significant improvements on this front is likely to disappoint in many developing countries. This does not mean that anti-corruption strategies are not desirable. It simply means we should not expect significant growth dividends from anti-corruption strategies delivering significant and sustained reductions in corruption. The sustainability of corruption reduction is particularly important. In many developing countries, sharp shocks from new anti-corruption agencies sometimes have a temporary effect on corruption, but over time, the tendency is for corruption to creep back. We will not discuss the reasons for this here, but we have discussed these extensively elsewhere (Khan 2006a, 2006b). What is relevant here is that if corruption cannot be significantly reduced in the medium term, we cannot expect a significant growth dividend from anti-corruption strategies.

A related problem with the good governance agenda is the assumption that all rents and rent seeking are damaging. Stiglitz and others have shown that a vast range of rents are essential for the proper functioning of market economies, even advanced ones (Stiglitz 1996; Khan 2000b). Rents are no less critical in developing countries. Indeed, the catching up and technology acquisition problems that developing countries face require significant rent-management capabilities on the part of governments if entrenched market failures are to be overcome. This is because assistance for technology acquisition necessarily creates rents. The only question is whether the rent is well-managed, resulting in growth accelerations or poorly managed, resulting in a waste of national resources. Clearly, while many rents are indeed damaging, others are second-best responses to market failures that would have worse effects without the rents. In such a context, targeting rent seeking in general without a strategy of distinguishing between different types of rents can be misleading. The strategy must be to realize that many rents can be damaging and others are vital for development and to develop governance capabilities to manage some of these essential rents. These capabilities are part of the critical growthpromoting governance capabilities that developing countries need to focus on. If growth-enhancing governance capabilities are initially limited, technology policies have to be cut to size, not done away with.

To some extent Collier implicitly recognizes the importance of rents for technology acquisition when he argues for preferential trade policies for Africa (Collier 2007) to give African countries a (temporary) differential advantage over Asia. Such a differential advantage provides temporary rents for African producers. Trade policy is an effective way of providing temporary rents for kick-starting investments in some 
sectors, but may not be sufficient in very technologically backward economies which face significant disadvantages not only in labour and management skills but also in physical infrastructure. Other types of temporary rents have of course been used in the past, but each strategy requires specific local governance capabilities if positive results are to be achieved.

\begin{abstract}
Democracy in developing countries is fragile and often works through patron-client networks. Clearly democracy is an end in itself and should be supported on these grounds alone (Khan 2005). But if we support democracy because we believe it is a mechanism that reduces rent seeking and corruption, we are likely to be frequently disappointed. Moreover, democracy in the least developed countries remains fragile because conflicts over resources are intense, particularly between competing political factions. Fiscal constraints in developing countries often mean that democracies find it difficult to deliver public goods for everyone and political stability is often dependent on the ability of the political system to deliver to powerful factions. In these contexts, programmes to increase democratic accountability may or may not directly assist the management of growth and productivity enhancement strategies. Sometimes, powerful patron-client factions who are the primary players in the democratic process in these countries are the very organizations that impede the efficient allocation of public resources, while at other times their competition may enable the introduction of reforms and the efficient allocation of resources (Jenkins 2000; Khan 2005). The only general conclusion that we can draw is that support for democracy in developing countries should not be justified by the assertion that democracy will always improve market efficiency. Rather, democracy deserves support as an end in itself, and should not be confused with the more difficult task of creating governance capabilities for supporting growth.
\end{abstract}

\title{
Specific problems attributed to Africa
}

The difficulty of implementing the good governance agenda in Africa has also had the unfortunate effect of reformers identifying a number of apparently specific African problems that have made progress difficult. In many cases the story of African exceptionalism is too pessimistic, though clearly Africa may have special problems with its size, historically lower population density and therefore generally less developed states. Nevertheless, where Africa is not exceptional at all is that no developing country has actually succeeded in implementing good governance at levels of per capita income that we see in Africa (Khan, this volume). The true African exceptionalism may be that Africa is now expected to do something that no-one else has done. We look at a number of areas where specific problems have been identified. These features point not to a significant difference in African challenges compared to general developing country problems but rather perhaps the need to go slower with ambitious reform programmes and developing growth-enhancing governance capabilities in more modest ways in countries with poor initial conditions.

Neo-patrimonialism and fragmented polities. The neo-patrimonial argument is that African states are distinctively pre-modern. This analysis goes back to Médard who has written a number of pieces, with the main arguments summarized in Médard (2002). The neo-patrimonial state contrasts with a modern Weberian state that is supposed to be impersonal, formal, accountable and non-corrupt. The neo-patrimonial state is the precise opposite, with personalized and informal relationships between the boss or patron and his clients. The patron is unaccountable and corrupt, treating the 
public domain as a private fief, and dispensing benefits to clients to stay in power. While all these characteristics are clearly visible in Africa, a comparative historical analysis shows that these features are common to all developing countries going through the developmental transformation. The scarcity of fiscal resources for providing generalized public goods means that in all developing countries variants of patron-client politics are used as a means of delivering to politically powerful constituencies whose support is vital for the survival of the ruling group (Khan 2005).

Médard argues that the problem in Africa is the absence of accountability that allows leaders to treat the public domain as their private fief. The policy suggested is the support of democratization and accountability as a way of weakening the hold of the personal power of the 'big men', thereby helping to make the state become more modern and Weberian. In this respect, the argument is close to the general good governance one summarized earlier in Khan (this volume). However, this theoretical argument is not supported by any historical observation from anywhere in the world that shows that democratization has systematically driven (rather than having followed or co-evolved in complex ways with) the emergence of a modern capitalist economy and the Weberian state that is associated with it (Khan 2005). In particular, democratization in developing countries does not do away with patron-client politics but does change their organization in ways that are sometimes more developmental and sometimes less. But because gradually building democratic institutions has longterm benefits, democracy should be pragmatically supported for its own sake.

A related issue is the political fragmentation of polities in Africa. For instance, Chabal and Daloz (1999) in an influential argument observed that in African states disorder was institutionalized. What they refer to is precisely the disorder that allows the transfer of resources down patron-client networks. The weakness of their argument is that what they refer to as a specifically African problem is actually a general characteristic of all developing countries. Or to put it differently, the institutionalization of order (stable property rights, entrenched democracy, low or negligible corruption, the accountability of leaders and so on) requires a significant level of development in order to be effectively implemented.

So what is distinctive about Africa? Chabal and Daloz, and many other commentators on Africa appear to be saying that African leaderships do not have the 'political will' to impose order to capture more significant productive surpluses by enhancing production compared to the easy surpluses available through unproductive means. Similar problems exist in many Asian countries and regions and I have argued that this problem is deeper than one of political will. Some societies have very fragmented polities, and the extent and type of political fragmentation in Asia can improve our understanding of the differential performance within Asian countries (Khan 1996b, 1999, 2000a). Some of these ideas have been developed in the African context by Lockwood (2005). This work suggests that the focus of attention should be on the institutional and political fragmentation of African states, and not just or even primarily on the political will, integrity or other characteristics of the leadership, important though these may also be in some contexts.

The performance of political leaderships can change dramatically with the political organizations they can deploy. This is because their capacity to enforce depends on the effectiveness of the political organizations they work with. It is widely recognized 
that a poor capacity to implement or enforce can result in predatory behaviour for a number of reasons. A lack of confidence in their ability to protect their own wealth in the future can induce elites to steal and export their capital. This is a variant of the argument put forward by Olson when he contrasted stationary bandits (a stable state where elites can expect to protect themselves in the future) with roving bandits (where elites are fragmented and short-lived) (Olson 2000). Similarly, poor political and institutional coordination can result in different parts of the state behaving in uncoordinated ways to raise revenue and inadvertently reducing their own incomes (Shleifer and Vishny 1993; Khan 1996a). Of course, building the political organizations and enforcement institutions that may eventually allow African societies to make more rapid transitions to productive economies is also a matter of conscious political activity. But the reference here is to collective political activity, not the political will of a specific leadership. And again, Africa does not face qualitatively different problems here compared to many Asian societies.

African Culture. A variant of the neo-patrimonial argument is that the personalized politics observed in Africa is supported by a specific African peasant culture. The 'economy of affection' that describes this culture in turn emerges in the fragmented economy of African agriculture where exchange has to be based on personalized relationships. Patrimonial politics results from this economy and the culture that it generates (Hyden and Williams 1994). But again, a comparison with the Asian experience suggests there is nothing unique about the African peasant economy. James Scott made exactly the same observations about the Asian peasantry in his account of the moral economy of the Vietnamese peasantry (Scott 1977). These accounts are consistent with our explanation that formal property rights and institutions cannot be sustained in poor economies since the underlying assets do not yet generate enough of a surplus to pay for their protection and the maintenance of a rule of law society that allows impersonal private contracting at low transaction cost. However, none of this precluded transitions to productive capitalist economies in Asia. It is not clear why peasant culture should be playing a significantly more negative role in Africa.

Ethnic fragmentation. A common perception is that Africa suffers from excessive ethnic fragmentation and many African states have not resolved fundamental questions about their territorial limits and ethnic compositions. The argument here is that this prevents any dominant group in an African polity acquiring the legitimacy to enforce rights or even decisions about the allocation of social resources at low cost. Moreover, the attempt by ruling groups to benefit their own tribe or region further exacerbates these underlying problems. There is an element of truth in this argument but ethnic fragmentation should not be overstated as an explanation of state weakness. The extent of fragmentation varies across African countries. Often conflicts over resources can take an ethnic form, but these conflicts would probably have been just as intense in ethnically homogenous societies where cleavages would have been organized along other lines. It is also worth remembering that many African countries are relatively new, having just emerged from colonial occupation as in Mozambique and Angola. The Asian experience of post-independence development shows that periods of considerable turmoil can follow independence even in ethnically homogenous societies (for example Bangladesh in the 1970s). 
It is equally important to remember that national identities even in states that now appear to be ethnically homogenous have always been the product of social engineering. Successful states in Asia and Europe created national identities with differing degrees of success. Asian states like Thailand that appear to be ethnically homogenous today, achieved this through very specific state policies of nationbuilding that were often not very pleasant for minorities (such as the Chinese in the case of Thailand who were forced to adopt Thai names and stop going to Chinese schools). These are not necessarily examples to emulate, but it is important to remember that ethnicity like nationhood is a construct. Then there are Asian states like India that in terms of ethnic, religious, caste and other cleavages should not even have lasted, but in fact emerged as one of the most effective states in the region. Again, simple answers like India works because of its democracy are too simplistic. India works because of complex internal bargains which also involve corrupt patronclient politics and often the exercise of significant amounts of state and non-state violence. Examples of states working to create homogenous or at least cohesive national identities are not absent in Africa: the case of Tanzania is particularly interesting because the creation of a composite national identity was one of the primary goals of the Nyerere years, and by all accounts, the results were quite remarkable in the African context. The Tanzanian experience shows that nation building is a long process where outsiders can contribute little but could potentially do much damage by suggesting easy options that may not exist.

Africa is a relative newcomer to the long centuries of ethnic wars and conflicts that have marked state building in Europe and Asia. This included two world wars which had their origins in European national conflicts. The lesson from the European and Asian experience should not be that Africa has a problem because it is too ethnically fragmented, but rather it should be that Africa has been relatively civilized so far in its several decades of building nation states compared to the human costs in Europe and Asia over the last few centuries. The question could be rephrased to ask how Africa could learn the lessons of state building from Europe and Asia so that it could progress in a less bloody and socially costly way. This way of asking the question focuses or mind on the historical process: democratic norms only took deep root in many European countries after centuries of national conflicts. While it is clear that a minimal national consensus is required for a society to embark on any development strategy, the challenge is to identify what needs to be done in terms of reform priorities once a minimal national consensus emerges in countries like Tanzania.

Africa's Resource Curse. It is often also argued that in many resource-rich African countries, the descent into predation stems from the easy availability of natural resource rents, while Asia was helped by the absence of these natural resource rents. The argument is that warring factions in Africa can sustain conflict by financing themselves using natural resources. Conversely, the leadership of resource-poor Asian countries had to concentrate on how to produce wealth through industrialization. But while the easy availability of resources can sustain conflict, it does not explain why fragmentation exists in the first place since the discovery of windfall incomes in a country with a cohesive state could be a spur to development. Industrialization requires resources for investment, and where states with some enforcement capacity exist, natural resources can be very helpful in generating resources for high rates of investment in industry or high value services. This strategy was very successfully followed, for instance, by Malaysia and more recently by Dubai. 
In themselves, natural resource rents do not have to be damaging (see for instance Khan 2000b). Indeed, these are necessary rents from an economic perspective, as they help to achieve a rate of extraction of natural resources that is closer to the sustainable or optimal level. As with all rents, the existence of natural resource rents will induce rent seeking and in some cases where easy rents are available, this rent seeking can divert economic and political entrepreneurs into unproductive activities to an excessive extent. While this is theoretically possible, there is no reason to believe that it is inevitable. Even in Africa, there are already plenty of counter-examples. Botswana's success has been based on natural resource rents but it has not succumbed to civil war. Ghana exports large amounts of gold but is relatively peaceful, and even Angola is moving into a more peaceful era despite being a major oil exporter and Africa's largest diamond exporter.

We can accept the argument that natural resources can sustain conflicts that would otherwise have to be fought using more primitive weapons, but this does not mean that in the absence of these rents the fragmented states would have become cohesive. Fragmented states without natural resources can always discover new ways of generating income to sustain conflict, ranging from drugs to intervening in conflicts in neighbouring countries. It is quite plausible for instance to argue that Saudi Arabia without the oil may have been more like Afghanistan than South Korea. Thus, without denying the complications (both positive and negative) created by the presence of natural resource rents, we need to ask why states remain institutionally fragmented and politically weak in some contexts but manage to reform themselves and become developmental in others. The Asian experience suggests that developmental states emerged in both resource poor countries (South Korea, Taiwan) as well as in resource rich countries (Malaysia). Equally, non-developmental states have persisted in many Asian countries that are resource poor, both coastal and otherwise (Nepal, Afghanistan, Myanmar, Cambodia, Laos to name a few). These observations are particularly relevant for Africa where large natural resource endowments should be seen as an opportunity rather than a curse. Institutional and governance capacities could develop that allow resource rich African countries to manage these rents for economic development.

However, some of the proposals coming from the good governance approach are likely to be impossible to implement and have problematic implications for the development of growth-oriented states. For instance, there is a frequent suggestion that hydrocarbon and mineral rents should be in ring-fenced development accounts that are pre-committed to service delivery expenditures, preferably in pro-poor public goods like health and education. These suggestions may appear to be a huge improvement on the corruption and capital flight that is often associated with mineral rents in many African countries, which are real enough problems. But it is hard to imagine how the expenditure of such large chunks of national income can be effectively de-linked from internal power structures for too long. This is likely to be another example of a good idea that on closer inspection turns out to be implausible as an implementable strategy in the long term. Nor is it clear given the market failures affecting investment in new technologies and sectors in these countries that ringfencing all these potential investment resources away from the ruling elites who are potential investors is necessarily a good idea. It may be a better long-term bet in many of these countries to develop effective governance capabilities for managing growth- 
enhancing strategies, however shaky the progress. Capital flight happens when countries fail to develop profitable investment opportunities for their elites. If mineral and hydrocarbon rents are even moderately efficiently used in investment strategies, the long-run outcome for the country is likely to be satisfactory. This is easier said than done, but an objective of developing indigenous investment capabilities is a very different one from developing ring-fenced accounts that are pre-committed to provide pro-poor public goods. Each requires different incremental steps and the construction of different political coalitions. But one may be more viable than the other.

\section{Growth-Promoting Governance Strategies}

A decade of reforms beginning in the 1990s including a big push on good governance reforms was associated with spurts of growth in a number of African countries. However, although there are variations across countries, manufacturing remains weak in Africa and agriculture faces serious constraints in terms of infrastructure and investment. Much of the growth in the 1990s, though by no means all, was associated with a commodity boom that included good performance not only for hydrocarbon and mineral producers but also for producers of some agricultural commodities like coffee. The challenge is to extend these growth gains into manufacturing and highervalue agriculture and services, and here the market failures discussed earlier (Khan, this volume) need to be addressed. Since low transaction cost markets cannot be achieved through good governance reforms, specific market failures constraining particular sectors and technologies have to be addressed in a sequential way.

Ambitious Growth-Promoting Strategies. Supporters of growth-promoting governance interventions often refer to the examples of the Asian countries, particularly in East Asia, which used extensive interventions including industrial policy to accelerate technology acquisition and move up the value chain at a more rapid pace than would have been likely without these interventions. These countries, which include South Korea, Taiwan, Malaysia and others demonstrate the possibility that extensive interventions across a range of sectors can achieve accelerated productivity growth and learning, and sequential moves up the value chain. Moreover, they managed to achieve these results without attempting or succeeding in achieving good governance as defined in the good governance consensus. However, their success was based on a different set of state capabilities and the very scale of their successful interventions suggests that it may not be possible to develop a growthenhancing governance strategy for poorly performing developing countries simply by looking at and attempting to imitate the governance capabilities of more successful developers. This is so for at least two different sets of reasons.

First, the more successful developers enjoyed more favourable historical endowments of institutions and political conditions to begin with, which amounted to significant governance capabilities in some areas. They also had some pockets of capitalist development, such that entrepreneurs and technological capabilities were present to a greater extent than in many of the poorest countries in contemporary Africa. These initial conditions allowed a range of interventions to be effectively policed in the sense that it was difficult for inefficient rent seekers to capture state created rents if they failed to produce results (the relevant literature is reviewed in Khan 2004).

But secondly, successful developers had many different strategies of overcoming market failures, backed by different governance capabilities that were appropriate for 
the strategies they were following. Success in each case depended on the country selecting economic instruments to correct market failures that it could actually enforce given its internal political settlement and institutional capabilities (Khan 2000a, 2006b). This is an important observation for many poorly performing countries, where overall governance capabilities are poorer and where it is therefore much more important to design interventions and governance reforms very carefully to achieve the maximum effect and to avoid failures that can easily happen if limited capacities are overstretched.

These observations suggest that the only viable strategy for most developing countries would be a less ambitious strategy that addressed some of the market failures that the good governance strategy is implicitly trying to address but without attempting the ambitious implementation strategies of either the good governance agenda or the East Asian developmental states. In this incremental strategy the goal would be to address critical market failures, but to focus on a few at a time using instruments and strategies that were most likely to be implementable given feasible improvements in targeted governance capabilities. The distinctive part of the alternative approach suggested here is that interventions to overcome market failures and governance capabilities appropriate for their effective implementation should be simultaneously identified and developed so that the feasibility of the strategy as a whole is addressed (Khan 2008b, 2008a; UNCTAD 2009).

Incremental Approaches to Governance Reform. While Africa is not necessarily exceptional, most African countries in common with many Asian ones suffer from fragmented polities, weak political organizations and elites that lack sufficient legitimacy to be fully confident of the future. These characteristics rule out ambitious growth-enhancing strategies and point to the need to develop careful country-specific strategies for enhancing growth by addressing specific market failures. Enforcement capacities and governance capabilities for addressing these problems are likely to be limited. In these contexts growth and governance strategies are more likely to succeed if they are narrowly defined and supported by pragmatic and limited instruments (Khan 2008b). These may make a big potential impact, provided some very specific and limited governance capabilities are developed to support these instruments.

If the question is put in such a pragmatic way, it is unlikely that we should conclude that in general there are no intermediate steps that a developing country could take to counter the types of market failure that slow down technology upgrading, learning, sectoral diversification and so on. But even here, the optimal strategy will be different in different countries because of differences in their initial conditions and in particular their governance and enforcement capabilities. We should expect that countries will have to go through a process of experimentation to identify the mix of instruments and strategies that are most likely to deliver results given their initial conditions and in particular their political settlements.

The link with Hirschman's ideas on entrepreneurial development in poor countries is very instructive (Hirschman 1958, 1967). In a series of pioneering works Albert Hirschman pointed out that the most limiting resource in a developing country was likely to be its supply of entrepreneurs. Trying to do too many things was therefore not a good strategy. Rather, an incremental approach that relied on disequilibria to attract scarce entrepreneurial capacity into the most important sectors would produce 
the best results. The aim of development strategy would be to identify areas of critical bottlenecks where entrepreneurial effort was likely to have the biggest spillover effects through backward and forward linkages. To a great extent, this approach to thinking about the problems of entrepreneurship is just as relevant for thinking about the problems of governance.

The pool of competent and committed personnel and resources that are available to make a dent on the problems of governance is if anything even more limited than the pool of potential entrepreneurs in many developing countries. The best use of this scarce resource is to identify a few agencies where the best 'administrative entrepreneurs' can be allocated to address specific market failures, say in technology acquisition for a particular sector or to ease labour training requirements in that sector, or to ease a constraint on industrial or agricultural land availability. And as in Hirschman's original argument, the critical condition for success would be that mistakes must not be allowed to continue for too long, and if the entrepreneurial capacities to solve problems did not emerge in particular projects, there had to be some process of exit otherwise the likely social costs were obvious.

Therefore a Hirschmanian incremental approach to governance would have a number of components: We should not stretch existing governance and productive capabilities too much by trying to do everything at once. Rather we should focus on a few areas that appear to be relatively obvious areas where growth could be further promoted (we will discuss what obvious means in this context later). The essential Hirschmanian insight is that we should not expect a scientific and conclusive ex ante identification of critical bottlenecks or constraints a society faces because success depends on the ex post effort put in by stakeholders into the process of discovery and experimentation and so results cannot be 'pre-planned'. What appears to be a good bet may turn out to be otherwise, and what appears to be an unlikely area may provide a challenge that results in the unexpected development of new productive and governance capabilities. Most importantly, therefore, we need to have good exit strategies for the few things that we do try, and not try to do things where vested interests are likely to be so strong that exit may be precluded. If we keep in mind these pragmatic pointers, we should be able, through a process that must involve both prior analysis but also some experimentation, to identify a pragmatic set of strategies for developing countries that recognize both the reality of pervasive market failure and the limited capacities for overcoming them.

The argument that governance priorities for developing countries should be modest and should focus on the most important constraints has already been powerfully made by a number of observers, including Rodrik and his team (Hausmann, et al. 2007). They have also pointed out that the detailed governance capabilities that have been found to work in different countries can vary widely (Qian 2003). However, Hirschman's perceptive observations made 50 years ago on the indeterminate nature of the feasibility studies that preceded the adoption of projects in developing countries are just as applicable today to the sophisticated 'growth diagnostics' methods that are often suggested for identifying binding constraints in developing countries (Hausmann, et al. 2007). When the binding constraint approach is actually used in different countries, different economists can come up with very different conclusions about what the binding constraint is. A lot depends on the methodologies different economists may use, their own methodological assumptions and their degree of 
knowledge about the country (Leipziger and Zagha 2006). The conclusion that the assessment of a binding constraint is a 'disciplined art' rather than a 'science' would not have surprised Hirschman at all.

Apart from the problem of the many different methodologies that different observers can use to assess binding constraints, the real difficulty, as Hirschman pointed out, is the uncertainty that comes from not being able to foresee future problems and opportunities that will open up with any strategy chosen. The importance of exit strategies, and therefore the importance of choosing areas of intervention where exit is more likely to be feasible if future problems appear can thus emerge as the critical issue. The issues of uncertainty, experimentation and therefore the necessity of exit strategies are critical issues that the binding constraints approach ignores.

Hirschman's approach suggests a different focus for attention. The focus here is not on how to identify and select in a scientific way the binding constraints that first need to be tackled to support growth. Rather the focus suggested by a Hirschmanian reading of development history is on how to develop new capabilities in a pragmatic experimental way through a process of experimentation and problem-solving that could not have been foreseen from the beginning. From this perspective, it makes sense to select a number of reasonably obvious starting points for capacity building that make sense in terms of challenges currently being faced by growth sectors in the country. The critical condition is rather that the priorities for capacity building should be selected in such a way that the political capacity for exit is assured if the results are not satisfactory.

It is here that we should focus, because we believe that in the poorest countries, reform can begin at various points and that typically it will not be possible to find or agree on a single binding constraint. The starting point is likely to depend on specific political possibilities and capabilities, and there are likely to be a number of obvious places where we could begin (Khan 2008b). If success is achieved in one sector, the capabilities and lessons learnt can then be transferred to strategies for other sectors. The simplest strategy for a country is to begin with sectors which have already achieved some global market presence or are close to doing so. This is a pragmatic way to begin because to identify market failures in abstract may be beyond the technical and planning capabilities of many least developed countries. However, every country has some sectors where growth has been higher than in others, and where exports are actually making some progress even if more could be achieved. If we begin with these sectors and ask how capacity expansion, technology upgrading and increases in value addition could be accelerated, government agencies and governance capabilities could be developed (in a Hirschmanian incremental way) that have broader application to other sectors.

The steps involved in such a strategy are summarized in Figure 1, based on Khan(Khan 2008b). Step 1 in Figure 1 is to identify a few sectors where growth policy (the investment and technology policy) should focus in terms of addressing constraints on further productivity enhancement and moving up the value chain. In most developing countries, there are a number of sectors where some growth has been achieved and a pragmatic approach would be to start with these sectors and ask what needs to be done to improve productivity, move up the value chain and enhance growth in these sectors. Unlike good governance type reforms, here we recognize that 
general governance improvements that would in theory impact on all sectors should not be the sole focus of governance or growth policies in poor countries. Once a number of initial sectors and bottlenecks have been identified in Step 1, the critical decisions are in Steps 2 and 3 in Figure 1, which are the stages at which a discussion of the requisite governance capabilities for the growth strategy comes into focus.

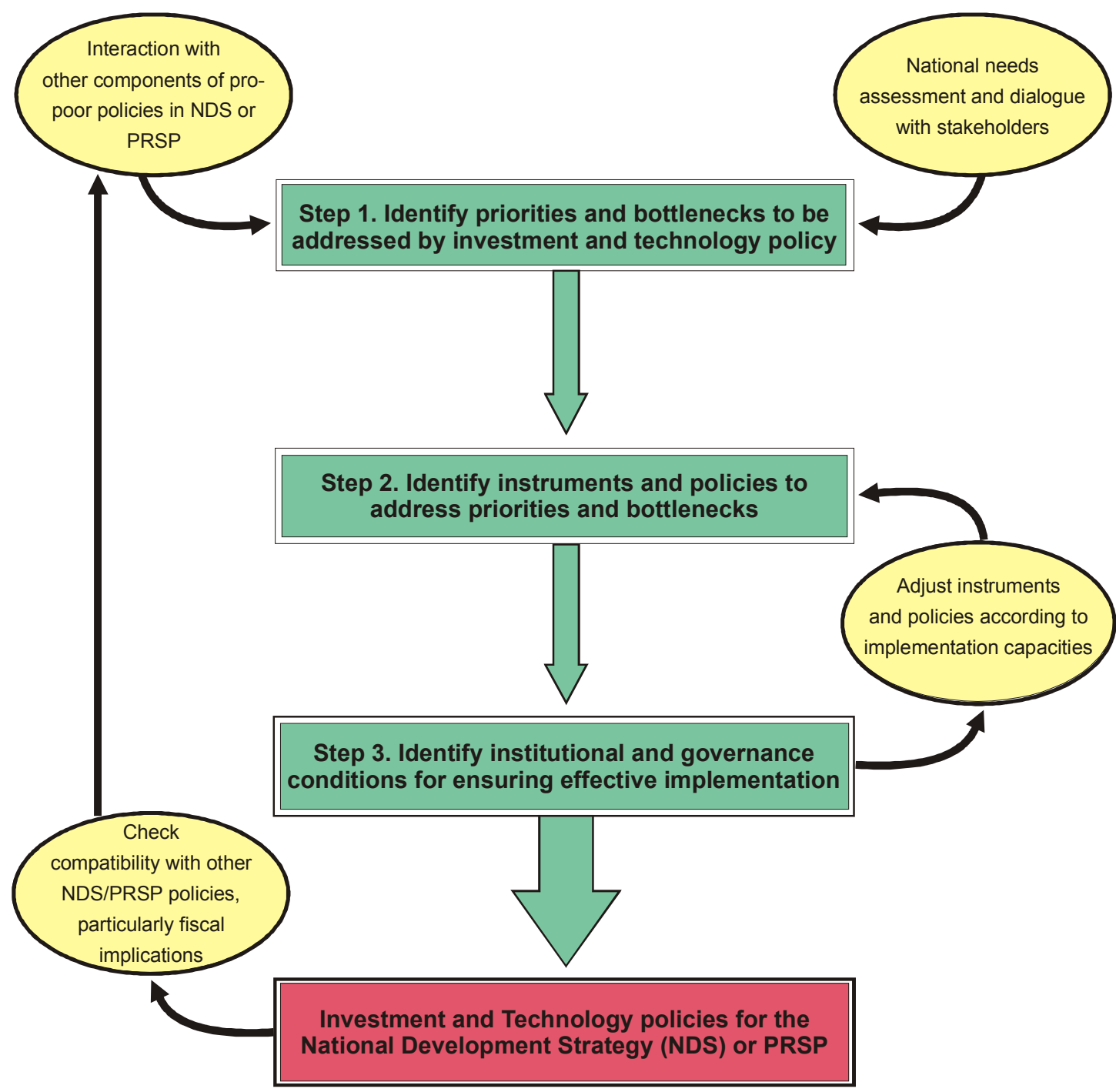

Source: (Khan 2008b: Table 1)

Figure 1 Steps in Developing a National Growth Strategy

The identification of 'obvious' sectors could be managed through a transparent process of evaluation and dialogue that involves key business organizations in the country. But while there may be debates at the margin about which sectors should be selected as the initial few for policy attention, the sectors that must be included will be less controversial. For instance, in Ethiopia, the leather sector, cotton textiles and cut flowers immediately attract attention as sectors that have already achieved some success. Or in Tanzania, cotton textiles, tourism and mining are obvious candidates for initiating the policy investigation. This is not to suggest that identifying the sectors that policy-makers should initially focus on is always going to be uncontroversial. There are likely to be intense conflicts in some countries where growing sectors that 
are not included feel that they have been discriminated against. For the policy process to be inclusive and transparent it is therefore important for as many as possible of there important sectors to be included, without diluting the efficacy of the policy dialogue excessively by including the whole (Khan 2008b).

By focusing on a few sectors and looking for the constraints that are preventing growth, it is more likely that market failures will be discovered in a pragmatic way that could be the target for specific policy interventions to correct these failures. The focus then shifts to Steps 2 and 3, which describe a process of iteration through which a number of narrowly defined instruments are selected such that agencies charged with their implementation already have the necessary governance capabilities to implement them effectively or these capabilities can be feasibly developed.

Even in a limited number of areas, the task of identifying plausible constraints created by market failures is not easy and requires the presence of capable policy-makers in key positions. The technical capacities in government agencies are often lacking and entrepreneurs themselves may have perceptions about what constrains their expansion that are based very closely on the consensus opinion of international financial institutions that are regularly reported in the national press. For instance, Doing Business surveys ask very limited questions of entrepreneurs on things like how long it takes to export and import, their opinions about infrastructure constraints and so on, but does not ask questions about whether poor labour skills made the business uncompetitive and the constraints preventing firm-level investments in these labour skills. These results are then reported back to the national media as an objective identification of the constraints facing business and soon a wide swathe of newspaperreading entrepreneurs in the country are likely to identify exactly the problems of governance and investment climate identified in these surveys as the problems constraining them (Khan 2008c).

There is no question that if electricity supply could be improved, if roads and ports appeared and if the bureaucracy became more efficient, enterprise across the board would benefit. But these are precisely the big ticket public goods that take a long time to develop and deliver. They should be developed but in the meantime the trick is to identify areas where there are potentially big returns to relatively small investments but where these investments will not be made by private investors because market failures prevent them from being assured of private returns or the private risk is too high. If policy attention in these areas actually sustained and even accelerated growth, the resources for the big ticket public goods would be more likely to be forthcoming in the future. Examples of the types of market failures that could be addressed follow.

Market failures affecting Investment in New Sectors and Technologies. In many developing countries, finance for potentially profitable manufacturing investment is simply not available. This could either be because the entrepreneurial base is so underdeveloped that existing entrepreneurs do not have the track record or collateral to borrow from commercial banks. Or it could be because banks have excessive risk premiums for productive investments and prefer to lend to consumers to finance consumer goods purchases. In other developing countries, finance may be available for a few rapidly growing sectors as long as entrepreneurs continue to invest in known technologies where the risk is low, but they may be forced to finance more risky 
investments on their own because banks or other outside investors do not want to share these risks.

These are all examples of potential market failures. Specific agencies providing relatively small amounts of seed capital for small scale investments in startups can have potentially large social benefits provided the caveats about exit strategies for programmes are adhered to. The development of entrepreneurial skills and the development of knowledge and capabilities to use new technologies are vital for most developing countries. It is a very big assumption to assume that the risk-sharing arrangements for these risky investments are likely to emerge through private contracting in contexts where contract enforcement is weak because of structural reasons. With public agencies absorbing some of these risks, some mistakes will inevitably be made, some rent seeking will take place and some entrepreneurs will fail for no fault of their own. But clearly these costs can be reduced significantly by limiting the programme to manageable proportions for that country and providing well funded and capable individuals in key agencies charged with delivering results. The examples of successful countries show that in the early days their success was typically based on islands of effective agencies operating in unpromising environments. These islands are likely to be even smaller and more modest in developing countries with less promising initial conditions. But it is still important to plan appropriately and develop these approaches.

An incremental growth-promoting governance approach in this context would be to work with existing financial institutions, the government and the private sector to develop feasible governance capabilities that allow existing financial instruments or ones similar to those used by other developing countries to be implemented to allow risk-sharing investments. The critical issue is not just to provide implicit subsidies to financing instruments, or for government to absorb some of the risks involved, but to have well-designed instruments so that the desired results are achieved. In particular, poor countries would be right to start with relatively small experiments with specific financial instruments and scale up if the governance capabilities for these instruments can be developed.

These market failures are of course well recognized in the market-promoting agenda. However, the standard good governance reform strategy is to make markets more efficient by focusing on rule of law reforms, anti-corruption strategies and competition policies. In theory, if a broad-based rule of law could be enforced, contract-enforcement would improve, allowing long-term profit-sharing investments including through stock markets. However, the practical question is whether these market-enhancing governance reforms can be implemented to a sufficient extent and soon enough to have any effect on these pressing market failures. How much further would contract enforcement, rule of law, anti-corruption and disclosure reforms have to proceed to allow firms with no track record to raise money in efficient capital markets from domestic venture capitalists willing to bet on the learning skills of particular entrepreneurs? The historical evidence suggests this is not likely to happen any time soon.

Labour Skills and Training. Despite being labour surplus economies, when it comes to manufacturing employment even in relatively low technology sectors, many poor countries appear to suffer from perennial labour shortages. Some of the shortages are 
due to shortages of specific skills, but there is also a shortage of 'unskilled' labour. The reason for the latter is that while labour is abundant, workers exposed to factory discipline and conditions of work in a high pressure export sector are difficult to find. The skills provided by formal school education are socially important but do not necessarily fill this gap. Firms in these countries therefore have to engage in on-thejob training but they systematically invest too little in this. At the same time, private sector training institutes for skilled workers have been set up in more advanced developing countries with larger manufacturing sectors. But here too there is low uptake and an unwillingness of employers to pay very much for training their workforce. These are clear examples of market failures. Training is available and required, but is not taken up despite employers facing serious shortages of skills. The problem is that the employer financing the training faces a market failure (externality) problem because the worker could leave the firm with the training and bargain for a higher wage elsewhere.

Once again, a number of simple solutions could address the market failures affecting labour skills and training. However, each solution requires specific governance capabilities on the part of the government to deal with that market failure. The possibility of long-term employment contracts with the personnel receiving training is one solution that is ruled out by the implausibility of enforcing such contracts in a developing country environment. This leaves the possibility of subsidizing the provision of training. The training at issue could range from orientation programmes for new entrants into the industrial workforce to very specific programmes of skill development required for specific technologies.

However, for a training scheme not to waste public funds, it would need to be carefully designed and managed, bringing us back to the issue of developing specific governance capabilities in selected agencies. Depending on the stage of development of the country, training could range from very simple to fairly sophisticated. Government could assist the solution of the market failures in a variety of ways including co-financing training programmes set up by industry associations, providing low or zero interest loans to workers attending accredited training programmes and so on. In each case the design of the programme would have to respond to industry needs as well as the capabilities of available public officials to monitor and implement the programme.

Land Allocation and the Achievement of Scale Economies. Market failures in the land market can be a serious constraint for new projects and for expansions in developing countries, particularly in relatively densely populated ones or ones where land rights are particularly poorly defined. Land typically does not have clearly established property rights in most developing countries. It is often difficult to establish clear ownership, there are often multiple claimants for most plots of land and the plot sizes are typically small. There are structural reasons for this, to do with the limited productivity of most land, and the high cost of establishing clear property rights on assets like land (Khan 2006c, 2009). Potential investors can face long and complex processes for acquiring a piece of uncontested land.

In the conventional good governance approach the solution to these problems is to improve the land market as a whole by improving land records, the court system and by fighting corruption, so that land market transactions can take place smoothly. The 
importance of land use regulation is obviously also recognized but by itself this will not solve the problem faced by industry if overall land market efficiency does not also improve. These good governance or market-enhancing governance strategies are clearly only likely to deliver in the very long-run. In contrast, an incremental growthpromoting governance approach would be to identify specific land bottlenecks and develop moderately efficient agencies to address land use problems in these priority areas.

The precise configuration of tasks and capabilities for a land agency would obviously vary from country to country, depending on the types of problems and the political and institutional initial conditions. One possibility is to charge it with the acquisition of land for industrial zones and to provide adequate infrastructural amenities. Such agencies exist in many countries but they are often ineffective. The prioritization of growth-enhancing governance capabilities is precisely to focus on vital areas. In developing countries where almost everything could be improved, the absence of prioritization often means that nothing gets done. The essential point is simply that the growth-promoting approach is about focusing on a limited range of things that can be done, and then ensuring that the highest quality personnel with clear political support are made available for these agencies. As with the other types of interventions discussed, the ability to change the policy and indeed to exit from strategies that are not working is critical for improving the chances of success.

\section{References}

Chabal, Patrick and Jean-Pascal Daloz 1999. Africa Works: Disorder as Political Instrument. Oxford and Indianapolis: James Currey and Indiana University Press.

Collier, Paul 2007. Growth Strategies for Africa. Paper prepared for the Spence Commission on Economic Growth. University of Oxford: Oxford.

Collier, Paul and Stephen A. O'Connell 2007. African Economic Growth: Opportnunities and Choices, in Ndulu, Benno J., Stephen A. O'Connell, Robert H. Bates and Paul Collier (eds) The Political Economy of African Economic Growth 1960-2000, Cambridge: Cambridge University Press.

Commission for Africa 2005. Our Common Interest: Report of the Commission for Africa. London: Commission for Africa.

Deininger, Klaus 2003. Land Policies for Growth and Poverty Reduction. The World Bank: Washington DC.

Hausmann, Ricardo, Dani Rodrik and Andrés Velasco 2007. Growth Diagnostics. Initiative for Policy Dialogue Working Paper Series. Columbia University: New York. Available HTTP: $<\underline{\text { http://policydialogue.org/files/publications/Ch_15.pdf }>}$

Hirschman, Albert O. 1958. The Strategy of Economic Development. New Haven: Yale University Press. 
Hirschman, Albert O. 1967. Development Projects Observed. Washington DC: The Brookings Institution.

Hyden, Goran and Donald C. Williams 1994. A Community Model of African Politics: Illustrations from Nigeria and Tanzania, Comparative Studies in Society and History 36 (1): 68-96.

Jenkins, Rob 2000. Democratic Politics and Economic Reform in India. Cambridge: Cambridge University Press.

Kaufmann, Daniel, Aart Kraay and Massimo Mastruzzi 2005. Governance Matters IV: Governance Indicators for 1996-2004. World Bank Policy Research Working Paper $\quad$ No. $3630 . \quad$ Available $\quad$ HTTP: $<$ http://www.worldbank.org/wbi/governance/pubs/govmatters4.html>

Khan, Mushtaq Husain 1996a. The Efficiency Implications of Corruption, Journal of International Development 8 (5): 683-96.

Khan, Mushtaq Husain 1996b. A Typology of Corrupt Transactions in Developing Countries, IDS Bulletin (Liberalization and the New Corruption) 27 (2): 12-21.

Khan, Mushtaq Husain 1999. The Political Economy of Industrial Policy in Pakistan 1947-1971. SOAS Department of Economics Working Paper No. 98, School of Oriental and African Studies, University of London. Available HTTP: $<$ http://eprints.soas.ac.uk/9867/1/Industrial_Policy_in_Pakistan.pdf $>$

Khan, Mushtaq Husain 2000a. Rent-seeking as Process, in Khan, Mushtaq H. and K.S. Jomo (eds) Rents, Rent-Seeking and Economic Development: Theory and Evidence in Asia, Cambridge: Cambridge University Press.

Khan, Mushtaq Husain 2000b. Rents, Efficiency and Growth, in Khan, Mushtaq H. and K.S. Jomo (eds) Rents, Rent-Seeking and Economic Development: Theory and Evidence in Asia, Cambridge: Cambridge University Press.

Khan, Mushtaq Husain 2004. State Failure in Developing Countries and Strategies of Institutional Reform, in Tungodden, Bertil, Nicholas Stern and Ivar Kolstad (eds) Annual World Bank Conference on Development Economics Europe (2003): Toward Pro-Poor Policies: Aid Institutions and Globalization, Proceedings of Annual World Bank Conference on Development Economics, Oxford: Oxford University Press and World Bank. Available HTTP: $<\underline{\text { http://eprints.soas.ac.uk/3683/1/State_Failure.pdf }>}$

Khan, Mushtaq Husain 2005. Markets, States and Democracy: Patron-Client Networks and the Case for Democracy in Developing Countries, Democratization 12 (5): 705-25.

Khan, Mushtaq Husain 2006a. Corruption and Governance, in Jomo, K.S. and Ben Fine (eds) The New Development Economics, London/New Delhi: Zed Press/Tulika. 
Khan, Mushtaq Husain 2006b. Determinants of Corruption in Developing Countries: the Limits of Conventional Economic Analysis, in Rose-Ackerman, Susan (ed.) International Handbook on the Economics of Corruption, Cheltenham: Edward Elgar.

Khan, Mushtaq Husain 2006c. Governance and Anti-Corruption Reforms in Developing Countries: Policies, Evidence and Ways Forward. G-24 Discussion Paper Series: Research Papers for the Intergovernmental Group of Twenty-Four on International Monetary Affairs and Development No. 42. United Nations Conference on Trade and Development: New York and Geneva. Available HTTP: $<\underline{\text { http://www.unctad.org/en/docs/gdsmdpbg2420064_en.pdf }>}$

Khan, Mushtaq Husain 2008a. Building Growth-Promoting Governance Capabilities. Background Paper for The Least Developed Countries Report 2008. UNCTAD: Geneva. Available HTTP: $<$ http://www.unctad.org/sections/ldc_dir/docs/lder2009 khan_en.pdf $>$

Khan, Mushtaq Husain 2008b. Investment and Technology Policies, in Department of Economic and Social Affairs (DESA) (ed.) National Development Strategies: Policy Notes, New York: United Nations. Available HTTP: $<\underline{\text { http://esa.un.org/techcoop/documents/PN InvestmentTechnologyPolicyNote.pdf }>}$

Khan, Mushtaq Husain 2008c. Technological Upgrading in Bangladeshi Manufacturing: Constraints and Policy Responses Identified in a Study of the ReadyMade Garments Industry. Unpublished Report. UNDP: Dhaka. Available HTTP: $<$ http://eprints.soas.ac.uk/9961/1/TechnologicalUpgrading.pdf $>$

Khan, Mushtaq Husain 2009. Governance Capabilities and the Property Rights Transition in Developing Countries. Research Paper Series on Governance for Growth. School of Oriental and African Studies, University of London: London.

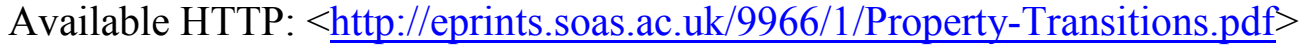

Leipziger, Danny M. and Roberto Zagha 2006. Getting Out of the Rut: Applying Growth Diagnostics at the World Bank, Finance and Development 43 (1): 16-17. Available HTTP: $<\underline{\text { http://www.imf.org/external/pubs/ft/fandd/2006/03/leipzige.htm }>}$

Lockwood, Matthew 2005. The State They're In: An Agenda for International Action on Poverty in Africa. Bourton-on-Dunsmore: ITDG Publishing.

Médard, Jean-François 2002. Corruption in the Neo-Patrimonial States of SubSaharan Africa, in Heidenheimer, Arnold J. and Michael Johnston (eds) Political Corruption: Concepts and Contexts, Third Edition, New Brunswick: Transaction Publishers.

Olson, Mancur 2000. Dictatorship, Democracy and Development, in Olson, Mancur and Satu Kähkönen (eds) A Not-so-Dismal Science: A Broader View of Economies and Societies, Oxford: Oxford University Press.

Qian, Yingyi 2003. How Reform Worked in China, in Rodrik, Dani (ed.) In Search of Prosperity: Analytical Narratives on Economic Growth, Princeton NJ: Princeton University Press. Available HTP: 
$<\underline{\text { http://ksghome.harvard.edu/ .drodrik.academic.ksg/Growth\%20volume/Qian- }}$

China.pdf $>$

Sachs, Jeffrey D., John W. McArthur, Guido Schmidt-Traub, Margaret Kruk, Chandrika Bahadur, Michael Faye and Gordon McCord 2004. Ending Africa's Poverty Trap, Brookings Papers on Economic Activity 2004 (1): 117-240.

Scott, James C. 1977. The Moral Economy of the Peasant: Rebellion and Subsistence in Southeast Asia. New Haven: Yale University Press.

Shleifer, Andrei and Robert W. Vishny 1993. Corruption, Quarterly Journal of Economics 108 (3): 599-617.

Stiglitz, Joseph E. 1996. Whither Socialism? Cambridge Massachusetts: MIT Press.

UNCTAD 2009. The Least Developed Countries Report 2009: The State and Development Governance. The United Nations Conference on Trade and Development: New York and Geneva. Available HTTP: $<\underline{\text { http://www.unctad.org/en/docs/ldc2009 en.pdf }>}$

World Bank 1993. The East Asian Miracle: Economic Growth and Public Policy. Oxford University Press: Oxford. 